\title{
$\mathrm{IMD}$ 공정 중 필름 변형 특성 파악을 위한 사출 및 필름성형 간 연계해석
}

\author{
윤 종 혁, 허 남 건, ${ }^{*}$ 배 아 현, ${ }^{2}$ 이 태 희 ${ }^{2}$ \\ ${ }^{1}$ 서강대학교 기계공학과 \\ 2삼성전자, 제조기술센터 요소기술팀
}

\section{COUPLED ANALYSIS OF INJECTION MOLDING AND FILM FORMING FOR IDENTIFYING FILM DEFORMATION IN IMD PROCESS}

\author{
J.H. Yoon, ${ }^{1}$ N. Hur, ${ }^{* 1}$ A.H. Bae $^{2}$ and T.H. Lee ${ }^{2}$ \\ ${ }^{1}$ Dept. of Mechanical Engineering, Sogang Univ. \\ ${ }^{2}$ Global Production Technology Center, Samsung Electronics Co., Ltd.
}

\begin{abstract}
In various manufacturing industries, an in-mold decoration (IMD) process for plastic objects is widely utilized because a film forming and an injection molding processes run simultaneously. In the present study, the deformation of polymer film and filling of resin in the IMD process were numerically investigated to evaluate the quality of the plastic object formed by the IMD process, which consists of thermoforming and injection molding processes. To obtain the initial shape of the polymer film during the injection molding process, the deformation of the polymer film in the thermoforming process was pre-formed using the vacuum conditions to attach the film to a cavity. Since the properties and deformation of polymer film are greatly affected by the behavior of polymer resin being injected into a mold cavity, numerical simulations for the injection molding and film forming were performed with one-way coupling method. The results showed that the injected resin could lead to the tearing of the polymer film in local regions near the corners. In order to verify the proposed numerical methodology, the numerical results of the deformation patterns printed on the initial polymer film were compared with the experimental data. The proposed methodology to couple film forming analysis with injection molding analysis can be used to predict the deformation of film in IMD process.
\end{abstract}

Key Words : 인몰드공정(In-Mold Decoration), 열성형공정(Thermoforming Process), 사출성형공정(Injection Molding Process), 일방향커플링기법(One-way Coupling Method)

\section{1. 서 론}

$\mathrm{IMD}$ 공법은 90 년대 후반에 개발된 공법으로 Fig. 1과 같이 열성형 공정에서 예비성형된 필름에 수지를 주입시켜 제품을 생산하는 공법을 말한다. 이러한 공법은 열성형 공정(고분자 의 얇은 필름이 진공압력에 의해 변형하여 필름층을 형성하 는 공정)과 사출성형 공정(용융된 고분자 수지가 주입된 후에 열전달에 의해 고화되어 사출물을 형성하는 공정)을 독립적으

Received: June 13, 2013, Revised: September 27, 2013, Accepted: September 27, 2013.

* Corresponding author, E-mail: nhur@sogang.ac.kr DOI http://dx.doi.org/10.6112/kscfe.2013.18.3.020

(C) KSCFE 2013
로 하던 종래의 방식과 다르게 이러한 공정들을 단 한번의 과정으로 수행할 수 있다는 점에서 생산 시간이 감축되고, 이 에 따라 대량생산이 가능하다는 이점이 있기 때문에 산업 전 반에 걸쳐 광범위하게 적용 및 응용되고 있다. 하지만 공정이 종료된 후에 고압, 고온의 조건에서 주입되는 수지에 의해 필 름의 표면에 찢어짐, 접힘과 같이 품질을 저하시키는 현상이 발생하여 이를 완화하기 위한 연구가 국내외로 다양하게 진 행되고 있다.

필름의 변형특성을 파악하기 위한 연구로는 Kim et al.[1] 이 Film Insert Molding (FIM) 공정 과정에서 예열된 필름이 금형에 흡착될 때 씨워지는 필름의 패턴 및 두께가 변화하는 현상에 대한 변화를 정량적으로 예측하였다. Phillips et al.[2] 은 IMD 공정 특성을 분석하기 위해서 금형을 이루는 금속에 


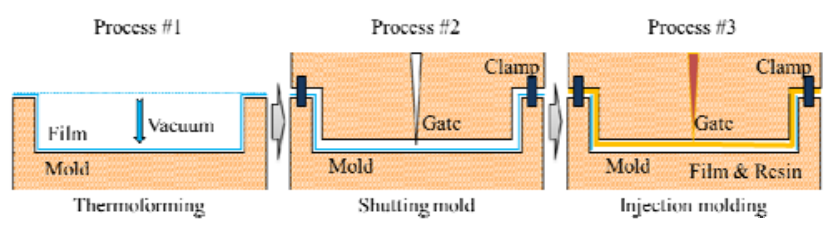

Fig. 1 Schematic diagram of IMD process

따른 영향성과 고압 성형공정에서 작용하는 다양한 설계 변 수가 필름의 성형 성능에 미치는 영향을 분석하였고, $\mathrm{Yu}$ et al.[3]은 직조형 NCF 섬유의 성형 공정 시 거동특성을 예측하기 위해 비직교 모델을 유한요소 프로그램에 결합시켜 수치해석적으로 분석하였다.

뿐만 아니라 $\mathrm{IMD}$ 공정에서 밀폐된 금형 내부에서 수지의 거동특성을 파악하기 위한 다양한 연구도 수행되고 있다. Tatara et al.[4]은 힌지가 달린 부품이 있을 때, 힌지의 유무가 유동패턴에 주는 영향성을 파악하였다. 이를 통해 힌지가 존 재하는 유무에 따라, 유동속도의 차이가 생겨 균일하지 못한 유동패턴이 나타나게 되고, 균일하지 못한 배열은 재료의 강 도를 저하시키는 문제점을 야기시킬 수 있다는 것을 확인하 였다. 또한 Hwang et al.[5]은 MP3 외장케이스에 대하여 IMD 성형 실험 시 최적의 성형조건을 얻기 위해 사출성형 해석을 수행하였다. 이를 통해 얻은 해석 결과를 토대로 사출성형 실 험을 수행하였고, 성형 완료된 제품에 대해 몇 가지 성능 테 스트를 시험하여 성형 성능을 평가하였다.

이처럼 IMD 공정 시 나타나는 수지 거동과 필름 변형에 대한 다양한 연구와 접근이 진행되고 있다. 하지만 이러한 연 구들은 수지의 거동과 필름의 변형에 대하여 독립적으로 진 행된 연구로서, 수지의 주입에 따른 필름의 변형 양상을 파악 하는 데는 한계점이 존재한다. 따라서 본 연구에서는 전자제 품의 플라스틱 외장 케이스를 대상으로 하여, IMD 공정에서 사출성형 공정과 열성형 공정에 대한 연계해석 방법을 정립 하여 IMD 공정 특성을 분석하였고, 사출성형 공정에서 주입 된 고분자 수지가 충진되는 양상에 따라 필름의 변형에 미치 는 영향을 파악하였다. 이와 같이 정립된 연계해석 방법을 검 증하기 위하여, IMD 공정에 대한 해석이 완료된 후 필름 표 면의 패턴의 변화를 실험과 비교하였다.

\section{2. 수치해석}

\section{1 지배방정식}

본 연구에서는 IMD 공정에서 금형 내부에 위치한 고분자 필름의 복합적인 변형 특성을 예측하기 상용 $\mathrm{FEM}$ 프로그램 인 PAM-FORM 2G professional 2009.1를 사용하였다. 이때 사 용된 고분자 필름은 점탄성 거동을 띄는 재료라고 가정하였
으며, 온도 변화에 따른 응력과 변형률, 응력과 변형속도의 관계를 보다 정확히 규명하기 위해 다음과 같은 비선형 점탄 성 구성방정식인 G'sell model을 적용하였다.

$$
\sigma=k[1-\exp (-w \varepsilon)] \exp \left(h \varepsilon^{2}\right)\left(\dot{\varepsilon} / \dot{\varepsilon}_{0}\right)^{m}
$$

여기서, $\sigma$ 는 응력텐서, $k$ 는 재료상수, $w$ 는 점탄성계수, $h$ 은 변형경화계수, $m$ 는 변형속도지수, $\varepsilon$ 는 변형률, $\dot{\varepsilon}$ 는 변형속 도, $\dot{\varepsilon}_{0}$ 는 기준변형속도를 나타낸다. 온도에 따른 물성변화를 고려하기 위해서, 4 개의 재료상수 $(k, w, h, m)$ 의 값은 $\mathrm{Kim}$ et al.[1]에서 사용한 재료상수 값을 적용하였다.

사출성형 공정 중에 밀폐된 금형내부에서의 수지의 거동을 육안으로 확인하기는 쉽지 않기 때문에, 이러한 유동적인 수 지의 거동을 예측하기 위해 상용 FEM 프로그램인 Moldflow 2012를 사용하였다. 용융된 고온의 수지가 금형내부에서 나타 내는 거동을 표현하기 위하여, 일반화된 뉴튼 유체에 대한 다 음과 같은 3 가지 보존방정식(연속방정식, 운동방정식, 에너지 방정식)을 바탕으로 한 Hele-Shaw 모델을 적용하였다.

$$
\begin{aligned}
& \frac{\partial}{\partial x_{j}}\left(\rho u_{j}\right)=0 \\
& \rho\left(\frac{\partial u_{i}}{\partial t}+u_{j} \frac{\partial u_{i}}{\partial x_{j}}\right)=-\frac{\partial p}{\partial x_{i}}+\frac{\partial}{\partial x_{j}}\left(\mu \frac{\partial u_{i}}{\partial x_{j}}\right) \\
& \rho c_{p}\left(\frac{\partial T}{\partial t}+u_{j} \frac{\partial T}{\partial x_{j}}\right)=\frac{\partial}{\partial x_{j}}\left(k \frac{\partial T}{\partial x_{j}}\right)+\mu \dot{\gamma}^{2}
\end{aligned}
$$

여기서, $u$ 는 수지유동속도, $p$ 는 압력, $c_{p}$ 는 비열, $k$ 는 열전도 도, $\rho$ 는 수지밀도, $\mu$ 는 수지점도, $T$ 는 수지온도, $\dot{\gamma}$ 는 전단률 을 나타낸다. 이때, 에너지 보존방정식에서 우변의 두 번째 항은 수지의 거동에 따른 점성에 의한 에너지 소산항을 의미 한다.

\section{2 해석 모델 및 해석 조건}

본 연구에서는 사용된 해석 모델은 플라스틱 외장 케이스 로서 실험시 사용했던 재료의 물성데이터와 작동 조건을 기 반으로 해석상에서 재료의 물성 및 해석 조건을 적용하였다. 이러한 정보를 기반으로 하여, 필름과 수지의 거동 간에 영향 을 파강하기 위하여, 필름성형 해석, 사출성형 해석, 필름 및 사출 연계해석을 단계적으로 수행하였다.

\subsection{1 열성형 공정에서의 필름성형 해석}

열성형 공정은 사출성형 공정을 수행하기에 앞서 필름의 대략적인 형태를 갖추기 위한 목적으로 수행되는 공정으로, 


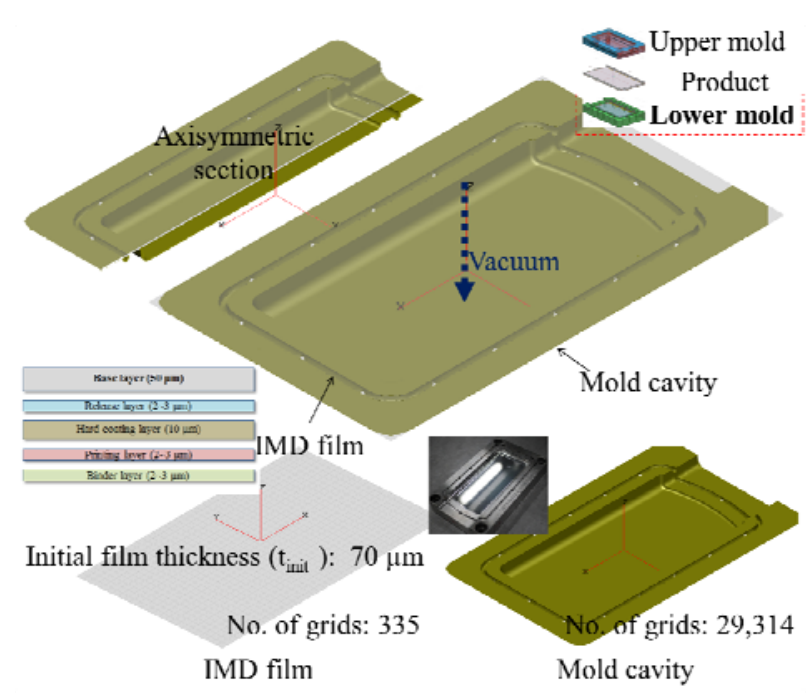

Fig. 2 Computational model in thermoforming process

실제 공정에서는 금형은 예열되어 있고 필름은 대기 중에 노 출되어 있으며, 필름 후면에 진공압을 가하여 필름이 금형에 흡착하는 방식으로 공정이 진행된다. 이러한 공정에서, 필름 의 변형특성을 파악하기 위한 해석 모델 및 해석 조건은 Fig. 2와 같다. 본 연구에서 사용한 해석 모델은 금형과 필름 으로 이루어져있으며, 각각의 대해 29,314개, 335개의 표면격 자를 생성하였다. 필름의 경우에는 변형 정도에 따라서 격자 가 분할되도록 설정하였다. 이때, 사용된 고분자 필름의 물성 은 $\mathrm{ABS}$ (Acrylonitrile Butadiene Styrene) 계열의 $\mathrm{IMD}$ 공정용 필 름의 물성을 적용하였고, 초기 필름의 두께는 $70 \mu \mathrm{m}$ 로 설정 하였다. 열성형 공정에서 금형 및 필름의 온도조건과 필름에 가해지는 압력조건을 Table 1 과 같이 필름성형 해석에 적용하 였다.

\subsection{2 사출성형 공정에서의 사출성형 해석}

사출성형 공정은 수지를 금형내부에 주입시켜, 용융된 수 지가 금형 내부를 채우면 열전달에 의해 용융된 수지의 온도 가 내려가 고화되며, 동시에 예비 성형된 필름을 수지층의 표 면에 씨워서 완전한 성형품을 생산하는 공정이다. 이때, 금형 의 바깥에 위치한 스크루의 회전에 의해 수지가 밀려오면서 금형내부로 수지가 충진되고, 금형내부의 모든 영역에 대해 수지를 가장자리의 영역까지 균일하게 충진시키기 위해 압력 을 추가적으로 가해주는 보압 공정이 진행된다. 이러한 사출 성형 공정 중에 밀폐된 금형내부에서 수지의 거동특성을 파 악하기 위한 해석 모델 및 조건은 Fig. 3과 같다. 해석 모델은

Table 1 Boundary conditions in thermoforming process

\begin{tabular}{|c|c|c|}
\hline \multirow{2}{*}{$\begin{array}{c}\text { Film forming } \\
\text { analysis }\end{array}$} & Mold temp. & $80^{\circ} \mathrm{C}$ \\
\cline { 2 - 3 } & Film temp. & $30^{\circ} \mathrm{C}$ \\
\cline { 2 - 3 } & Pressure & $0.2 \mathrm{MPa}$ \\
\hline
\end{tabular}

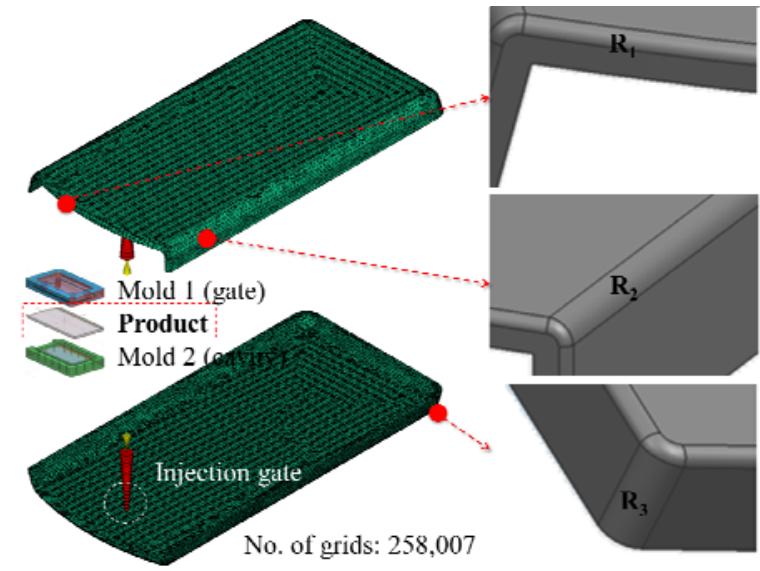

Fig. 3 Computational model in injection molding process

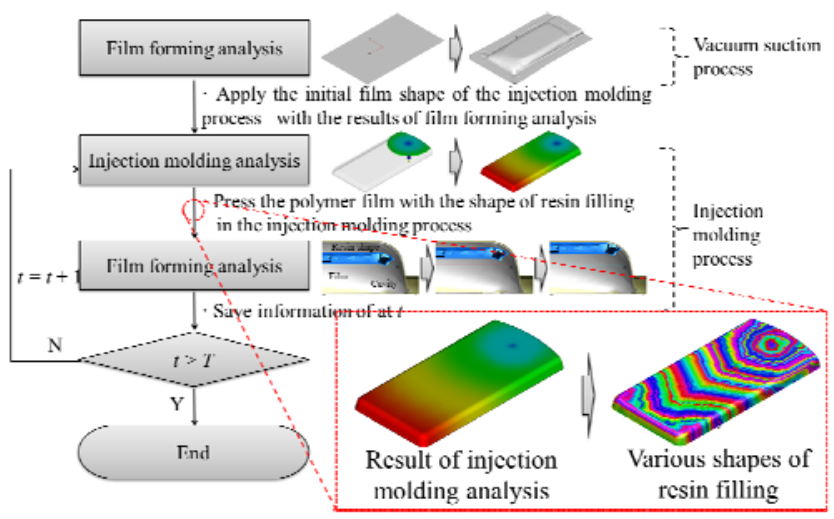

Fig. 4 Numerical procedure of coupled analysis

수지가 충진되는 영역과 노즐과 유사한 형태인 수지주입 게 이트로 구성되어 있으며, 수지가 충진되는 영역에 대해 258,007 개의 체적격자를 생성하였다. 이때, 실험에서 사용했던 PC/ABS (Polycarbonate \& Acrylonitrile Butadiene Styrene) 계열 의 수지 물성을 사출성형 해석에 적용하였다. 수지 및 금형의 온도조건과 수지의 충진속도 및 보압조건은 Table 2 와 같이 사출성형 해석에 적용하였다.

\subsection{3 필름 및 사출성형 간 연계해석}

사출성형 공정에서 밀폐된 금형 내부의 용융된 수지의 거

Table 2 Boundary conditions in injection molding process

\begin{tabular}{|c|c|c|}
\hline \multirow{4}{*}{$\begin{array}{c}\text { Injection molding } \\
\text { analysis }\end{array}$} & Mold temp. & $80^{\circ} \mathrm{C}$ \\
\cline { 2 - 3 } & Resin temp. & $250^{\circ} \mathrm{C}$ \\
\cline { 2 - 3 } & Ram speed & $35 \mathrm{~mm} / \mathrm{s}-35 \mathrm{~mm}$ \\
\cline { 3 - 3 } & - ram position & $48 \mathrm{~mm} / \mathrm{s}-12.5 \mathrm{~mm}$ \\
\cline { 2 - 3 } & Holding pressure & $38 \mathrm{~mm} / \mathrm{s}-0 \mathrm{~mm}$ \\
\cline { 2 - 3 } Film forming & - time & $80 \mathrm{MPa}-1 \mathrm{sec}$ \\
\hline analysis & Mold temp. & $80^{\circ} \mathrm{C}$ \\
\cline { 2 - 3 } & Resin shape temp. & $250^{\circ} \mathrm{C}$ \\
\cline { 2 - 3 } & Resin shape vel. & $400 \mathrm{~mm} / \mathrm{s}$ \\
\hline
\end{tabular}




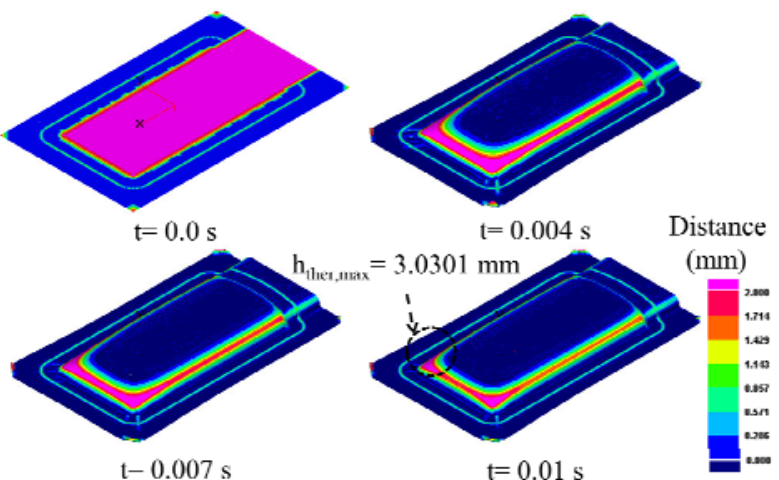

(a) Distance between film and mold cavity

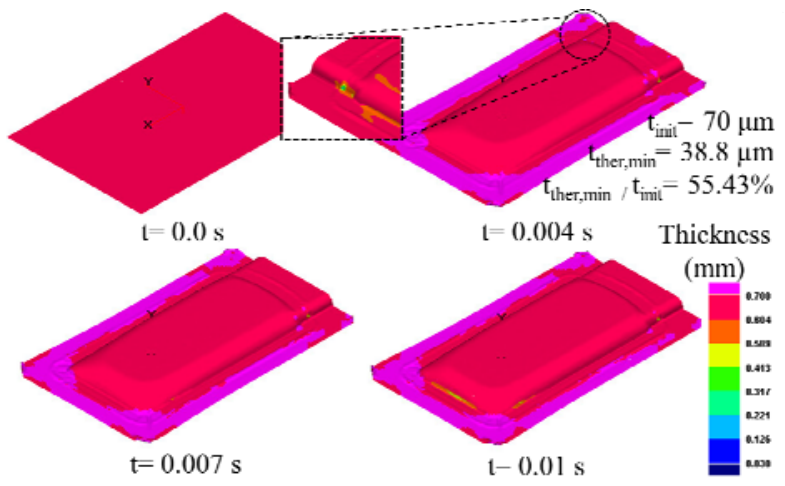

(b) Film thickness

Fig. 5 Deformation of a film in the thermoforming process

동이 필름에 미치는 영향을 파악하기 위하여 필름 및 사출성 형 간의 연계해석을 수행하였고, 이에 대한 흐름도는 Fig. 4와 같다.

\subsection{4 사출성형 공정에 대한 필름성형 해석}

사출성형 해석 후에 얻은 수지충진 특성에 대한 결과를 이 용하여, 전체 해석시간인 0.6021 초를 0.004 초의 시간간격에 따 라 총 150 개의 수지충진 형상을 획득하였다. 이러한 수지충진 형상을 열성형 공정에서 예비 성형된 필름에 수직으로 순서 대로 압착시키는 방법으로 필름성형 해석을 수행하였다. 이러 한 필름성형 해석에서 적용한 필름, 금형, 수지충진 형상에 해당하는 온도조건과 수지충진 형상이 필름을 압착 속도는 Table 2와 같다.

\section{3. 수치해석 결과}

\section{1 해석 결과}

본 연구에서는 제안된 필름 및 사출성형 연계해석을 통해 필름 변형특성을 파악하였다. 이러한 해석을 통해, 수지의 거 동 및 금형의 형상적인 특징에 의해 국부적으로 필름의 두께 가 달라지는 것을 확인하였다.
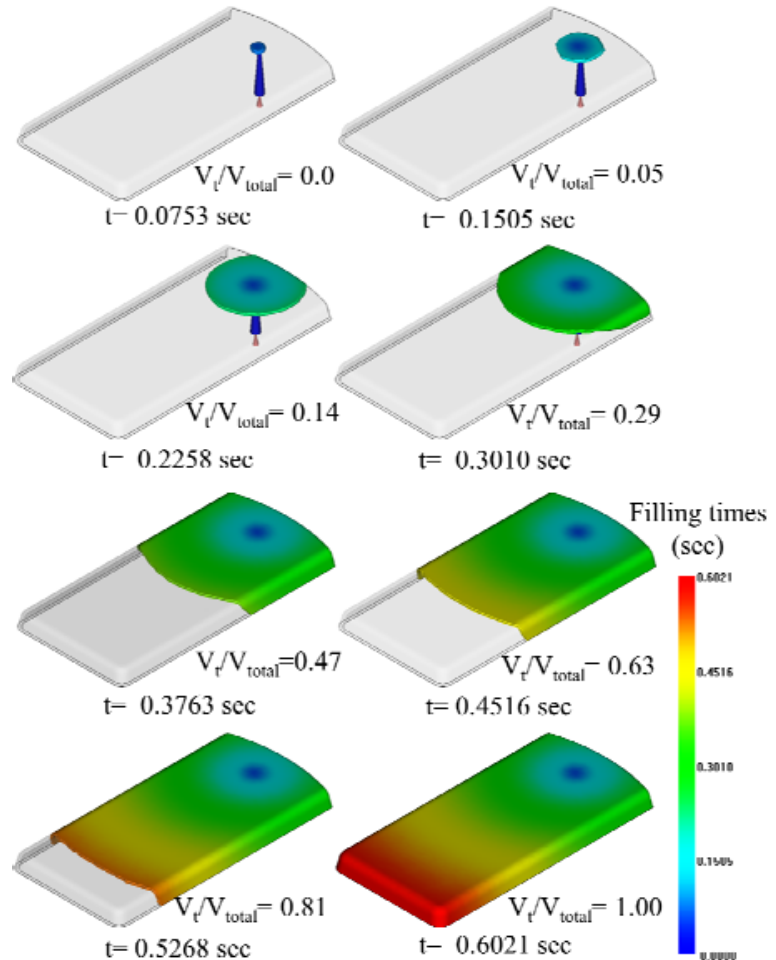

Fig. 6 Filling of resin into a cavity in the injection molding process

\subsection{1 열성형 공정에 대한 필름성형 해석 결과}

열성형 공정 후에 진공압에 의한 필름성형 해석 결과는 Fig. 5와 같다. 필름이 금형에 접촉하게 되면 필름과 금형간의 마찰저항에 의해 필름의 움직임이 정지되고 더 이상 변형이 일어나 않게 되어, 필름이 금형에 접촉했을 때의 두께가 곧 공정후의 필름의 최종 두께가 된다. 따라서, Fig. 5(b)와 같이 금형의 형상적인 특징으로 인해, 필름의 중앙부에서는 모서리 또는 코너와 같은 영역보다 쉽게 금형과 접촉하게 되어 거동 이 더 이상 발생하지 않고, 이에 따라 필름이 거의 인장되지 않기 때문에 필름의 초기 두께와 거의 차이를 보이지 않는다. 반면에, 모서리와 코너와 같은 주변부에서는 필름의 내부의 응력과 진공압이 평형상태에 도달할 때까지 인장이 발생하여 중앙부에 비해 두께가 얇아지는 것을 확인할 수 있다. 이때, 최소두께를 갖는 영역의 두께는 $38.8 \mu \mathrm{m}$ 로서 초기 두께의 약 $55.43 \%$ 만큼 두께가 감소한 것을 확인할 수 있다. 또한 Fig. 5(a)와 같이 금형과 필름 사이의 거리에 대한 결과를 토 대로, 모서리와 코너와 같은 영역에서는 금형의 형상적인 특 징에 의해 필름이 금형에 완전히 흡착되지 않는 것을 확인할 수 있었다.

\subsection{2 사출성형 공정에서의 사출성형 해석 결과}

수지의 거동을 파악하고, 시간에 따라 충진되는 수지의 형 상을 얻기 위해 사출성형 해석을 수행하였다. Fig. 6과 같이 


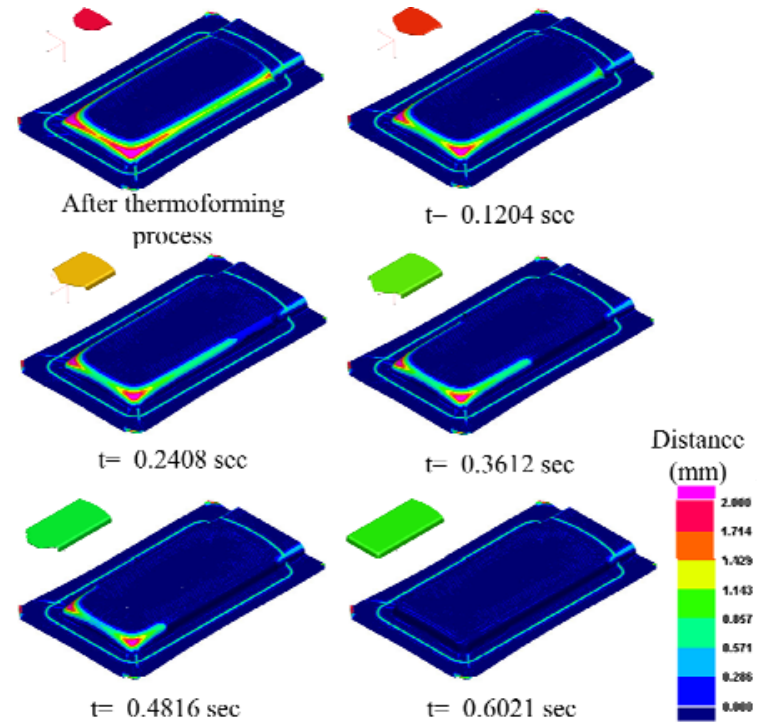

(a) Distance between film and mold cavity

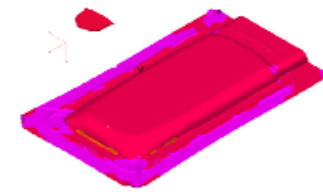

After thermoforming process
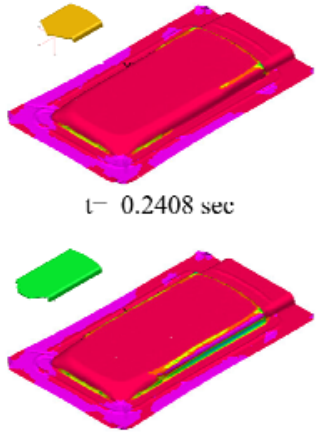

$\mathrm{l}=0.4816 \mathrm{sec}$

(b) Film thickness
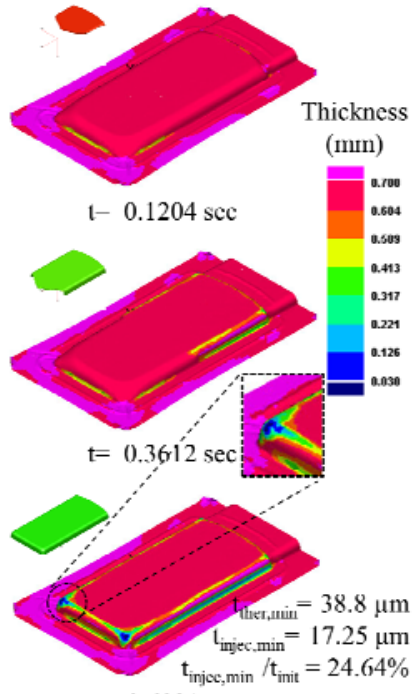

$\mathrm{t}=0.6021 \mathrm{sec}$

Fig. 7 Deformation of a film in the injection molding process

단일게이트에서 주입되는 수지는 게이트를 중심으로 동심원 모양을 그리며 외곽 영역으로 퍼져나가면서 충진되고 0.6021 초에 수지의 충진이 완료된다. 이러한 충진과정에서 금형내부 로 주입된 수지는 금형과 온도 차에 의한 열전달이 발생하여 수지의 온도가 점차 낮아지게 되고, 수지의 온도가 연화점 이 하로 낮아지게 되면 수지는 유동적인 거동특성을 잃게 되고 고화 및 경화되어 최종 사출물을 형성하게 된다.

\subsection{3 사출성형 공정에서의 필름성형 해석 결과}

이와 같이 수행된 사출성형 해석 결과로부터 시간에 따라 충진되는 수지의 형상들을 다수 획득하였다. 이러한 형상들을 이용하여 필름을 수직으로 압착시켰을 때 나타나는 필름의

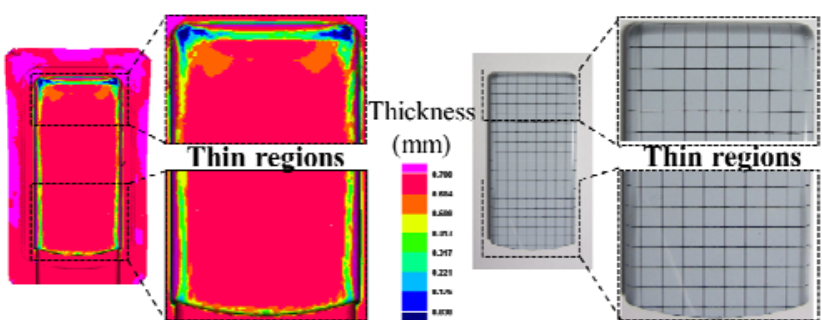

(a) Numerical result

(b) Experimental result

Fig. 8 Comparison of numerical results of thickness variation with the experimental results

변형특성은 Fig. 7과 같다. 필름이 완전히 흡착 되었는가를 나 타내는 금형과 필름 사이의 거리 결과로부터, 열성형 공정 후 에 모서리와 코너와 같은 영역에서, 필름이 흡착되지 않는 현 상이 연계해석 후에는 완전히 개선된 것을 Fig. 7(a)를 통해 확인할 수 있다. 또한 이러한 영역에서는 Fig. 7(b)와 같이 평 균적으로 두께가 더 얇아진 것을 확인할 수 있다. 또한 모서 리와 코너 영역에서 형상적인 이유로 인해 국부적으로 더 많 은 변형이 발생하는 것을 확인할 수 있다. 이때, 최소두께를 가지는 영역은 열성형 공정 시 필름과 금형사이의 거리가 가 장 멀었던 영역과 일치한다. 이때, 최소두께는 약 $17.25 \mu \mathrm{m}$ 로서, 초기 두께의 약 $24.64 \%$ 만큼 두께가 감소한 것을 확인할 수 있다. 이는 수지충진 형상이 필름을 압착시킬 때, 압착되 는 영역의 주변영역에 인장이 발생하게 된다.

\section{2 수치해석 결과 검증}

본 연구에서 제안된 연계해석 방법을 검증하기 위해 해석 과 실험의 필름의 변형특성을 비교하였다. 매우 얇은 필름의 두께를 직접 측정하기는 쉽지 않기 때문에 실험상에서 우선, 흰색의 필름에 검정색의 수지를 주입하였고, 공정 종료 후에 필름층의 밝기를 정성적으로 비교하였다. Fig. 8(b)에서 확인 할 수 있듯이 모서리와 코너와 같은 영역에서 흰색 필름층의 색이 어둡게 보이는 것을 확인할 수 있다. 이는 모서리와 코 너 영역에서 과도한 변형에 의해 상대적으로 얇아진 필름층 을 통해 검정색의 수지층이 투과하여 보이는 것이다. 이러한 변형양상은 해석결과에서도 유사하게 나타나는 것을 가시적 으로 Fig. 8(a)에서 확인할 수 있다.

또한 보다 정량적인 비교를 위하여, 초기에 필름의 표면에 $5 \mathrm{~mm}$ 의 정사각형 모양의 패턴을 입혔으며, 해석 종료 후 정 면 및 측면의 패턴변화를 나타내기 위해 제품의 길이방향 $(x$ 축) 위치를 전체 길이 $(L=97.1546 \mathrm{~mm})$, 너비방향 $(y$ 축) 위 치를 전체 너비 $(W=48 \mathrm{~mm})$, 높이방향 $(z$ 축 $)$ 위치를 전체 높이 $(H=6 \mathrm{~mm})$ 를 기준으로 무차원하여 정량적으로 표현하 였고, Fig. 9에 이와 같은 변수들을 도시하였다.

필름의 변형 패턴에 대한 수치해석결과를 실험과 비교함에 


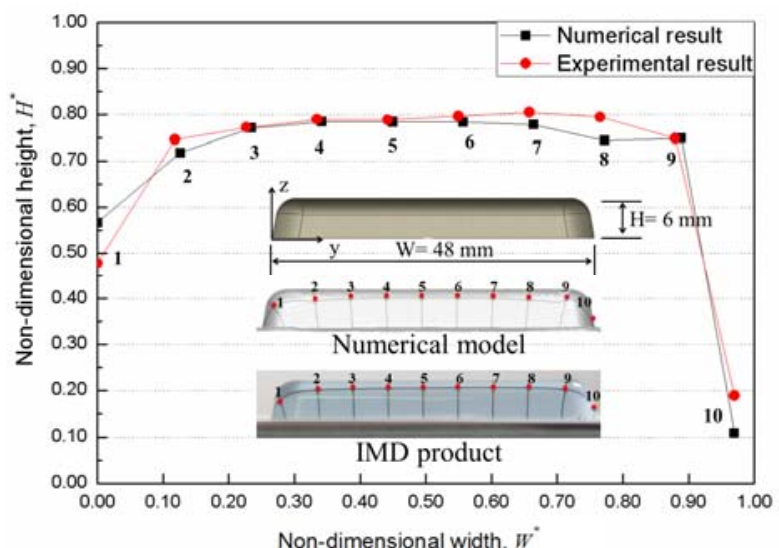

(a) Front view

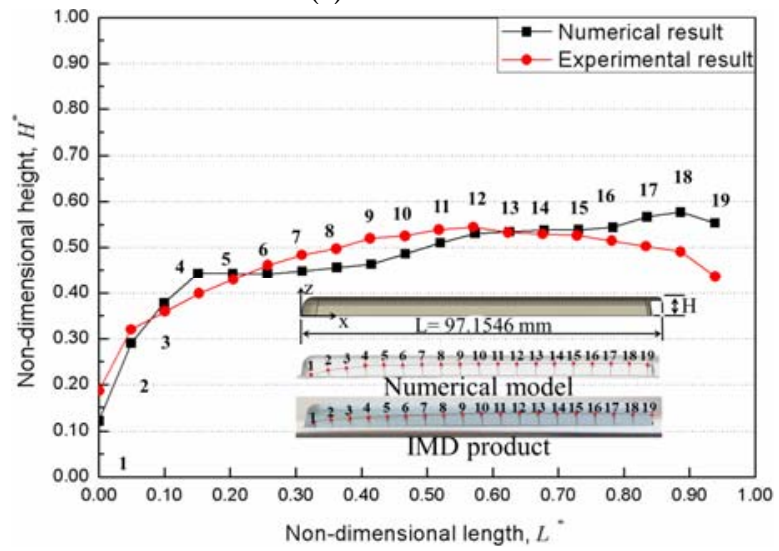

(b) Side view

Fig. 9 Comparison of the numerical result of deformed patterns on the IMD product with the experimental result

있어서, 실험에서 필름패턴의 초기 위치를 해석상에서 동일하 게 일치 시키는데 다소 어려움이 있어 약간의 오차가 발생하 는 영역이 존재하였으나, 전반적으로 유사한 경향성을 나타내 는 것을 확인하였다. 이와 같이, 필름 변형 패턴 비교를 통해, 본 연구에서 제안한 해석기법의 타당성을 검증하였다.

\section{4. 결 론}

본 연구에서는 플라스틱 커버에 대한 $\mathrm{IMD}$ 공정 특성 예측
을 위해 사출/필름 성형에 대한 연계해석 방법을 정립하였다. 이러한 결과를 통해 수지가 주입됨에 따른 필름의 국부적인 변형 특성을 파악하였다. 이와 같이 본 연구에서 제안한 필름 및 사출성형 연계해석방법은 $\mathrm{IMD}$ 공정 시 주입되는 수지가 필름에 미치는 영향을 파악하는 기본 자료로 활용될 것으로 기대한다.

\section{후 기}

이 논문은 2013년도 정부(미래창조과학부)의 재원으로 한 국연구재단의 지원을 받아 수행된 연구임(No. 201331018.01).

\section{References}

[1] 2009, Kim, G.Y., Lee, K.G. and Kang, S.S., "Prediction of the Film Thickness Distribution and Pattern Change during Film Insert Thermoforming," Polymer Eng. and Science, Vol.49, pp.449-464.

[2] 2009, Phillips, C.O., Bould, D.C., Claypole, T.C. and Gethin, D.T., "Finite element modelling of low temperature forming of polymer films with application in in-mould decoration," Materials and Design, Vol.30, pp.537-550.

[3] 2003, Yu, W.-R., Harrison, P. and Long, A., "Finite element forming simulation for non-crimp fabrics using a non-orthogonal constitutive equation," ACMC/SAMPE Conference on Marine Composite, Issue 8, Vol.36, pp.1079-1093.

[4] 2006, Tatara, R.A., Sievers, R.M. and Hierzer, V., "Modeling the injection molding processing of $a$ polypropylene closure having an integral hinge," Journal of Materials Processing Technology, Vol.176, pp.200-204.

[5] 2006, Hwang, J.E., Lee, D.W., Kim, J.S., Kang, T.H., Kim, I.K. and Kim, Y.S., "The Research on Injection Molding Process of In-mold for 3D Nurb Surface," KSMPE, pp. 292-297. 